\title{
Mineral Nutrient Acquisition by Cotton Cultivars Grown under Salt Stress
}

\author{
Ibrahim Ilker Ozyigit ${ }^{a}$, Ilhan Dogan ${ }^{b, c}$, Goksel Demir ${ }^{d}$, and Ibrahim Ertugrul Yalcine \\ aFaculty of Sciences \& Arts, Department of Biology, Marmara University, Goztepe, Istanbul, Turkey; ${ }^{\text {bFaculty of }}$ \\ Science, Department of Molecular Biology \& Genetics, Izmir Institute of Technology, Urla, Izmir, Turkey; 'Faculty of

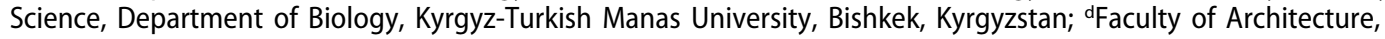

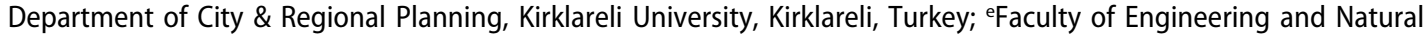 \\ Sciences, Department of Molecular Biology \& Genetics, Bahcesehir University, Besiktas, Istanbul, Turkey
}

\begin{abstract}
Physiological responses were investigated in two cotton cultivars grown at various concentrations of sodium chloride $(\mathrm{NaCl})$ in order to determine the degree of the tolerance of the cultivars to salt stress and understand the physiological responses with respect to utilization of mineral nutrients. After germination of the seeds of cotton cultivars, they were transferred into standard pots with $210 \mathrm{~g}$ sterilized compost and watered with $30 \mathrm{ml}$ Hoagland's solution containing different concentrations $(0,50,100,200$, and $400 \mathrm{mM}$ ) of $\mathrm{NaCl}$ at two-day intervals for 3 months. Growth parameters were measured and the mineral nutrient analyses were done using inductively coupled plasma optical emission spectrometry (ICP-OES, Thermo Fisher Scientific, Waltman, MA). It was observed that plant growth and mineral nutritional status of both cultivars were altered extensively in those grown with $\mathrm{NaCl}$. Excess $\mathrm{NaCl}$ reduces the concentrations of certain mineral nutrients and increases that of others, the patterns depending on the mineral nutrient and the plant part and varieties being compared to the control.
\end{abstract}

\section{ARTICLE HISTORY}

Received 13 March 2012

Accepted 1 December 2016

\section{KEYWORDS}

Cotton; Gossypium hirsutum L; mineral nutrition; salinity stress

\section{Introduction}

Since plants do not have mobility, exposure to stresses cannot be avoided in their environment but rather plants must adapt to ambient conditions. Low or elevated temperature, high salinity, drought, and presence of heavy metals, as well as pathogen and insect attacks are common stresses that plants encounter. Even with the best use of available land and sustainable farming practices, the impact of these abiotic and biotic stresses can severely reduce both food and fiber crop yields.

High soil salinity is a major limitation to crop production. Plant physiologists and breeders have long sought to develop efficient approaches to identify tolerant genotypes and understand their genetic and physiological mechanisms coping with salt. To this end, a great deal of research into impacts of salinity on plant physiology and development has generated a wealth of information in recent decades. The response of plants to salinity stress occurs as morphological, physiological, and metabolic responses and modifications in plant organs such as decreased seed germination, shoot and root length, and alteration of hydrolytic enzyme activity during germination and other metabolic processes (Akbarimoghaddam et al., 2011; Seckin, Sekmen, and Turkan 2009). Disrupted plantwater relations and ion balance due to the reduced water potential and high sodium levels in soil cause water loss and nutritional limitation in plants (Ali et al. 2001), leading to impairment of 
photosynthetic capacity (Bor, Ozdemir, and Turkan 2003; Netondo, Onyango, and Beck 2004; Tiwari et al. 2010) and cellular metabolic processes (Javid et al. 2011; Seckin, Sekmen, and Turkan 2009; Tabur and Demir 2010). Limited or excess of nutrient availability can result in retardation of plant growth (Berry 2010; Donohue 2001; Kudoyarova et al. 2015). Salinity influences the metabolism of mineral nutrients leading to reduction in plant growth indirectly as a result of nutrient imbalance and physiological disorders (Bano and Fatima 2009; Munns 2002). The most common salt found in the environments is sodium chloride $(\mathrm{NaCl})$, which competes with the uptake of other nutrients causing nutrient deficiency and specific toxicity in plants (Bano and Fatima 2009; Tester and Davenport 2003).

Cotton is an important commercial fiber crop widely cultivated throughout the world (Chachar, Solangi, and Verhoef 2008). Besides being utilized in the textile industry, cotton is also used for the production of various goods such as hulls, oil, linters, and food for animals (Aragao et al. 2005; Mishra et al. 2003). The cotton, which belongs to the genus Gossypium from Malvaceae family, is a deciduous, indeterminate perennial plant. Gossypium genus includes 51 species with tropical and subtropical distributions. The cotton is distributed worldwide and its wild members are inhabited in all continents, with exceptions of Europe and Antarctica (Ozyigit and Gozukirmizi 2008; Aguilera and Aguilera-Gomez, 2016).

There are large differences in plant species' response to salinity (Flowers, Munns, and Colmer 2014; Shrivastava and Kumar 2015). Plants exhibiting tolerance to salt can still manage to grow when grown on soils containing high levels of salt. Although cotton is considered a salt tolerant crop (Dong 2012; Mahajan and Tuteja 2005), its growth and yield are retarded markedly under high salinity stress, especially during germination and emergence stages (Ashraf 2002). Comparisons among cotton species have shown varietal differences in the levels of salt tolerance (Ashraf 2002; Hussain et al. 2012).

The two cotton cultivars (Nazilli $84 \mathrm{~S}$ and Cukurova 1518) used in this study are widely planted in Turkey (Ozyigit and Gozukirmizi 2008). Physiological responses of these two cotton cultivars grown at various concentrations of $\mathrm{NaCl}$ were investigated with respect to utilization of mineral nutrients to determine the degree of the tolerance of these cultivars to salt stress and to gain a better understanding of the physiological responses in terms of how mineral nutrition uptake could be used to develop efficient strategies for minimizing the detrimental effects of salt stress.

\section{Materials and methods}

The seeds of cotton cultivars Nazilli 84 S and Cukurova 1518 were surface-sterilized by immersion of ethyl alcohol $(70 \%)$ for $1 \mathrm{~min}$ and then washed with distilled water several times. They were germinated on wet filter paper in a growth chamber for 7 days and watered with full strength Hoagland nutrient solution (Hoagland and Arnon 1950). After 7 days, they were transferred into standard plastic pots containing $210 \mathrm{~g}$ of sterilized compost (Gardol $\mathrm{pH}$ : 6-7, electrical conductivity (EC): 1-2 m S/cm, safety: min. 95\%). Plants were grown under $5000 \mu \mathrm{mol} \mathrm{m}^{-2} \mathrm{~s}^{-1}$ fluorescent light, $23 \pm 2{ }^{\circ} \mathrm{C}$ temperature and $45-50 \%$ relative humidity at $16 \mathrm{~h}$-day / $8 \mathrm{~h}$-night regime. Upon appearance of second mature leaves, each experimental group (10 replicated seedlings) was watered with $30 \mathrm{ml}$ Hoagland's solution containing different concentrations $(0,50,100,200$, and $400 \mathrm{mM})$ of $\mathrm{NaCl}$ at two-day intervals for 3 months. The $\mathrm{pH}$ value was in range of 6 to 7 in control and experimental groups $(\mathrm{NaCl}$ treatment).

At the end of three-month experimental period, the seedling were harvested for analysis. The growth parameters such as stem length, leaf area, and fresh and dry weight of leaves/stems were measured. Followingly, leaf and stem samples were separated and then they were oven-dried at $80{ }^{\circ} \mathrm{C}$ for $24 \mathrm{~h}$, ground in a micro-hammer cutter and passed through a $1.5-\mathrm{mm}$ sieve. Plant samples $(0.5 \mathrm{~g})$

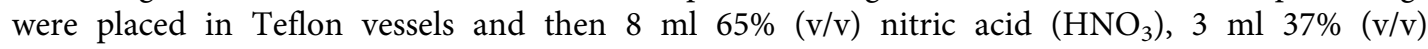
hydrochloric acid $(\mathrm{HCl})$ and $2 \mathrm{ml} 48 \%(\mathrm{v} / \mathrm{v})$ hydrogen fluoride $(\mathrm{HF})$ were added. Samples were mineralized in a microwave oven as follows: at $145^{\circ} \mathrm{C}$ for $5 \mathrm{~min}$., at $165^{\circ} \mathrm{C}$ for $5 \mathrm{~min}$. and at $175{ }^{\circ} \mathrm{C}$ 
for $20 \mathrm{~min}$. After cooling, the samples were filtered with Whatman filters (Macherey-Nagel, 640de/ $125 \mathrm{~mm}$ ), and diluted to $50 \mathrm{ml}$ with ultra pure water. Mineral elements boron, calcium, iron, potassium, magnesium, manganese, sodium, and zinc ( $\mathrm{B}, \mathrm{Ca}, \mathrm{Fe}, \mathrm{K}, \mathrm{Mg}, \mathrm{Mn}, \mathrm{Na}$, and $\mathrm{Zn}$ ) were measured by Inductively Coupled Plasma Optical Emission Spectroscopy.

All calculations were based on the parameters including the concentrations of the elements of leaves and stems, fresh and dry weights of leaves, lengths of stems and leaf areas of both cotton varieties. Using IBM SPSS 20 statistical software, the multivariate analysis of variance (MANOVA) with Tukey's post-hoc honest significant difference (HSD) and Pearson correlation analyses were performed. Statistically significant levels are given as ${ }^{\star *} p<0.01$ and ${ }^{\star} p<0.05$ (2-tailed).

\section{Results and discussion}

Figures 1-6 show the effects of $\mathrm{NaCl}$ concentration on the plant stem length, leaf area and fresh and dry weights of the two cotton cultivars. As shown in Figures 1-6 increasing $\mathrm{NaCl}$ concentration gradually inhibited the growth rate of both cultivars. The inhibition of growth pattern was similar in both cultivars but Cukurova 1518 showed a better tolerance to $\mathrm{NaCl}$ (Reduction rates in growth parameters were lower for Cukurova 1518 indicating better survival ability). Decreases were seen in the stem length of both cultivars (Figure 1). For leaf area, notable decreases were also observed for both cultivars (Figure 2). Overall there were significant decreases by $\sim 65 \%$ for Cukurova 1518 and $\sim 73.98 \%$ for Nazilli 84 S in stem length and by $\sim 84.53 \%$ for Cukurova 1518 and $\sim 89.87 \%$ for Nazilli $84 \mathrm{~S}$ in leaf area under severe salt stress $(400 \mathrm{mM} \mathrm{NaCl})$. Data obtained from Figure 1 and 2 revealed that stem lengths and leaf areas of both cultivars substantially decreased with the increase of $\mathrm{NaCl}$ concentrations compared with the control seedlings. After 90 days of $\mathrm{NaCl}$ exposure, growth rates decreased from $0.808 \mathrm{~g}$ to $0.144 \mathrm{~g}(\sim 82.18 \%)$ and $0.963 \mathrm{~g}$ to $0.067 \mathrm{~g}(\sim 93.04 \%)$ for leaf fresh weights and from $2.684 \mathrm{~g}$ to $0.312 \mathrm{~g}(\sim 88.37 \%)$ and $3.064 \mathrm{~g}$ to $0.300 \mathrm{~g}(\sim 90.2 \%)$ for stem fresh weights and from $0.174 \mathrm{~g}$ to $0.0355 \mathrm{~g}(\sim 79.6 \%)$ and $0.161 \mathrm{~g}$ to $0.024 \mathrm{~g}(\sim 85.09 \%)$ for leaf dry weights and from $0.600 \mathrm{~g}$ to $0.132 \mathrm{~g}(\sim 78.0 \%)$ and $0.682 \mathrm{~g}$ to $0.190 \mathrm{~g}(\sim 72.14 \%)$ for stem dry weights of Cukurova 1518 and Nazilli 84S, respectively (Figures 3-6). Also, for some growth parameters, there were fluctuations. For example, for stem dry weight, increases at low level $(50 \mathrm{mM})$ of $\mathrm{NaCl}$ treatment (from $0.600 \mathrm{~g}$ to $0.732 \mathrm{~g}, \sim 22.0 \%$ for Cukurova 1518 and from 0.682 to $0.853 \mathrm{~g}, \sim 25.1 \%$ for Nazilli $84 \mathrm{~S}$ ) and reductions at high level $(400 \mathrm{mM}$ ) of $\mathrm{NaCl}$ treatment (from 0.600 to $0.132 \mathrm{~g}, \sim 78.0 \%$ for Cukurova 1518 and from 0.682 to $0.190 \mathrm{~g}, \sim 72.1 \%$ for Nazilli $84 \mathrm{~S}$ ) were observed (Figure 6).

Previous studies showed that deleterious effects of salt ions on plant growth may result largely from altered metabolic activities, carbon-use efficiency, protein synthesis or enzymatic activities and

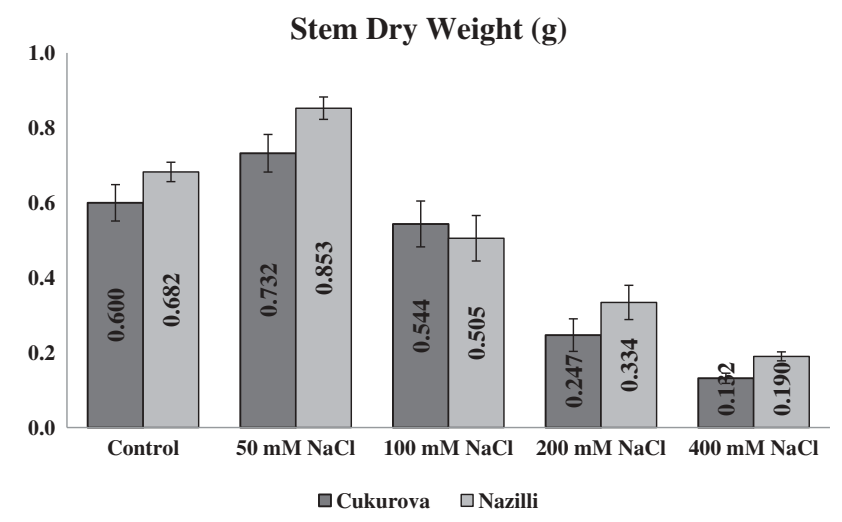

Figure 1. Stem lengths of cotton cultivars in different $\mathrm{NaCl}$ levels $(0,50,100,200$ and $400 \mathrm{mM})$ in three months of growing period. According to the results of variance analysis and Tukey's test, the mean difference is significant at $p<0.01\left(^{*}\right)$ and $p<0.05\left(^{* *}\right)$ levels. 


\section{Leaf Area $\left(\mathrm{cm}^{2}\right)$}

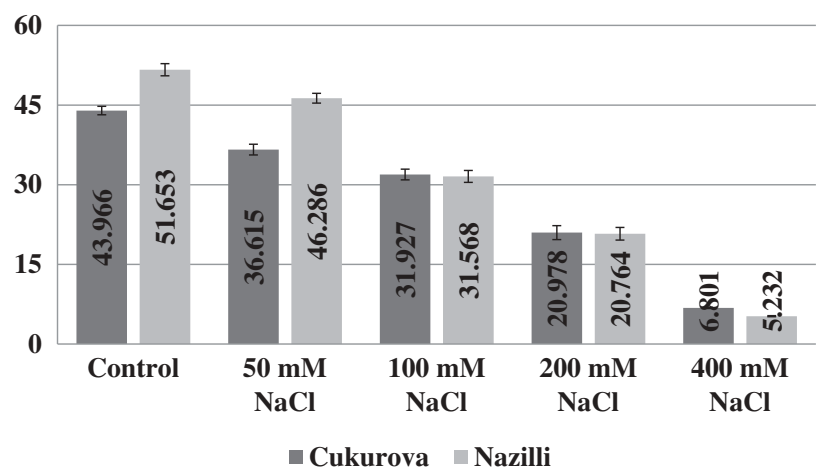

Figure 2. Leaf areas of cotton cultivars in different $\mathrm{NaCl}$ levels $(0,50,100,200$ and $400 \mathrm{mM})$ in three months of growing period. According to the results of variance analysis and Tukey's test, the mean difference is significant at $p<0.01\left(^{*}\right)$ and $p<0.05\left(^{* *}\right)$ levels.

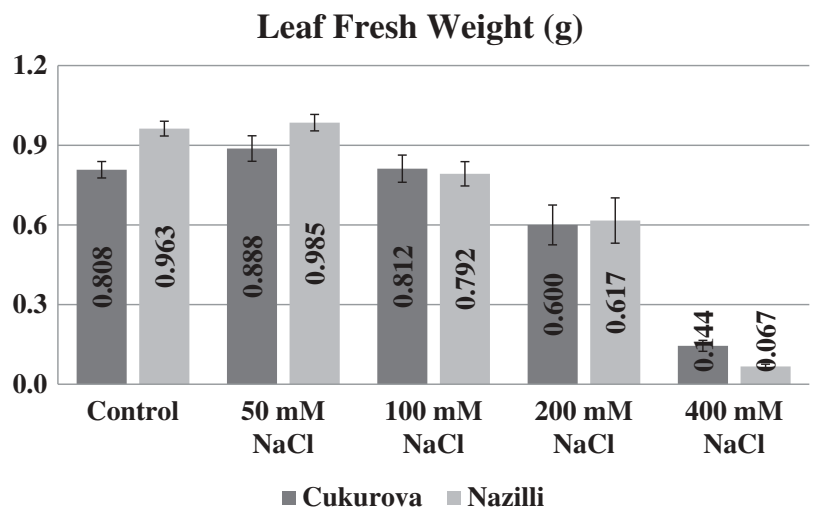

Figure 3. Leaf fresh weights of cotton cultivars in different $\mathrm{NaCl}$ levels $(0,50,100,200$ and $400 \mathrm{mM})$ in three months of growing period. According to the results of variance analysis and Tukey's test, the mean difference is significant at $p<0.01(*)$ and $p<0.05$ $(* *)$ levels.

osmotic potential leading to disruption of cell wall extension and cellular expansion (Glenn, Brown, and Blumwald 1999; Munns 1993; Neumann 1997; Staple and Toenniessen 1984; Zhu 2001). Under osmotic stress, absorbing water and micronutrient uptake by the roots of plants are reduced, and root-to-shoot transportation of micronutrients becomes problematic due to the impaired active transport and membrane permeability, and restricted transpiration rates (Alam 1999; Pasternak 1987). Overall, $\mathrm{NaCl}$ is known to have negative effects on plant growth and our results are consistent with the information given above.

Table 1 shows $\mathrm{Na}^{+}$concentrations after 3 months in leaves and stems of the two cotton cultivars, Cukurova 1518 and Nazilli 84S, grown in different $\mathrm{NaCl}$ levels. $\mathrm{Na}^{+}$concentrations in Cukurova 1518 and Nazilli $84 \mathrm{~S}$ increased dramatically with increasing $\mathrm{NaCl}$ levels. There was a difference in $\mathrm{Na}^{+}$concentrations among the leaves and stems of Cukurova 1518 (Table 1, see Na). The concentrations of $\mathrm{Na}^{+}$increased significantly in leaves (from 62.03 to $8698.5 \mathrm{mg} / \mathrm{kg} \mathrm{dw}, \sim 140.23 \mathrm{fold}$ ) and stems (from 416.38 to $9608.2 \mathrm{mg} / \mathrm{kg} \mathrm{dw}, \sim 23.08$ fold) of Cukurova 1518 (from control to $400 \mathrm{mM}$ treatment) (Table 1). Nazilli $84 \mathrm{~S}$ exhibited a similar trend (from 164.9 to $24470.0 \mathrm{mg} / \mathrm{kg} \mathrm{dw}, \sim 148.4$ fold in leaves and from 352.7 to $18417.8 \mathrm{mg} / \mathrm{kg} \mathrm{dw}, \sim 52.22$ fold) (from control to $400 \mathrm{mM}$ treatment) (Table 1). The increase in $\mathrm{Na}^{+}$concentrations between plants receiving no $\mathrm{NaCl}$ and those with 


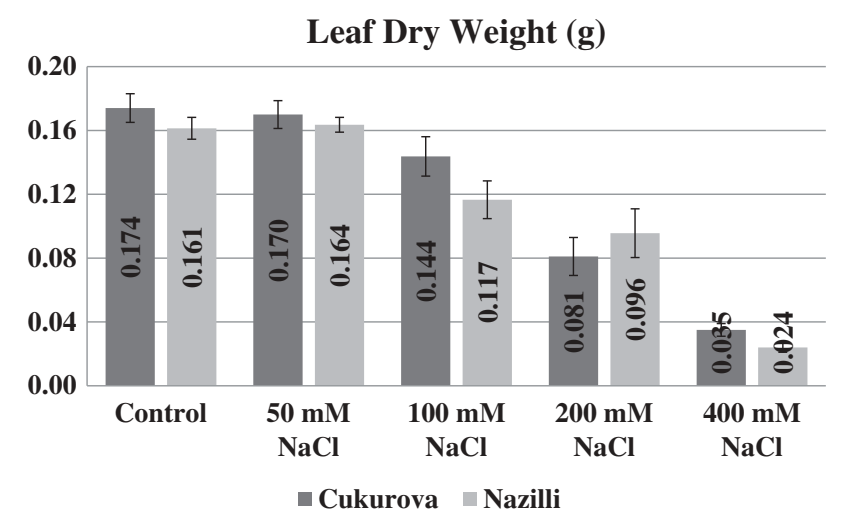

Figure 4. Leaf dry weights of cotton cultivars in different $\mathrm{NaCl}$ levels $(0,50,100,200$ and $400 \mathrm{mM})$ in three months of growing period. According to the results of variance analysis and Tukey's test, the mean difference is significant at $p<0.01\left({ }^{*}\right)$ and $p<0.05$ $(* *)$ levels.

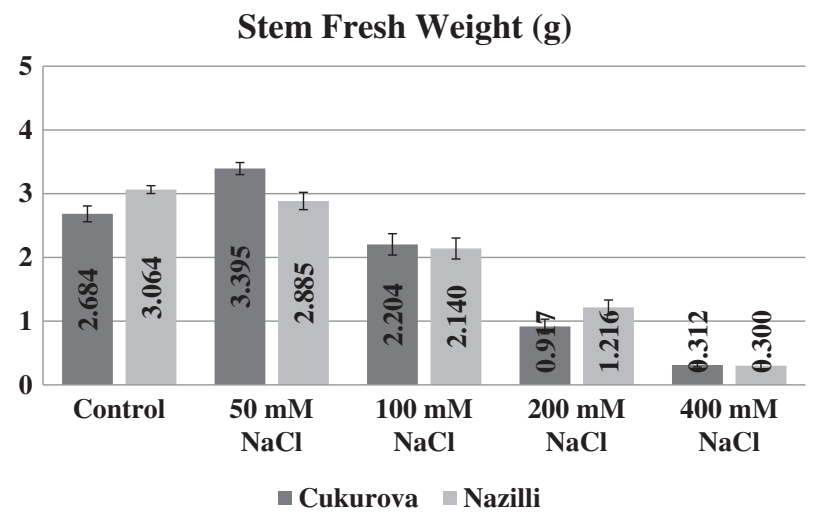

Figure 5. Stem fresh weights of cotton cultivars in different $\mathrm{NaCl}$ levels $(0,50,100,200$ and $400 \mathrm{mM})$ in three months of growing period. According to the results of variance analysis and Tukey's test, the mean difference is significant at $p<0.01\left(^{*}\right)$ and $p<0.05$ $(* *)$ levels.

$400 \mathrm{mM} \mathrm{NaCl}$ were about 148 fold in leaves and 52 fold in stems of Nazilli 84S. Sodium accumulated excessively in leaf and stem parts of both cultivars, but the accumulation rates were different in two cultivars (Cukurova 1518 and Nazilli 84S) indicating the difference in the adaptive response to salinity of the cultivars. In Nazilli $84 \mathrm{~S}, \mathrm{Na}$ accumulated more rapidly with increasing amount of exogenous salt than the Cukurova 1518 (Table 1, see $\mathrm{Na}$ ).

Mineral nutrient status of both cultivars was altered by salinity resulting in significant differences in the concentrations of mineral nutrients (Table 1). The concentrations of several mineral nutrients increased at a low level of $\mathrm{NaCl}$ but gradual reductions were observed with increasing $\mathrm{NaCl}$ concentrations in leaves and stems of the both cultivars. For example, for $\mathrm{K}, \mathrm{Mg}, \mathrm{Zn}$, and $\mathrm{B}$, following the increases at low levels of $\mathrm{NaCl}$, reductions were observed in leaves of Nazilli $84 \mathrm{~S}$ at higher levels of $\mathrm{NaCl}$ (from 14873.7 to $13428.6 \mathrm{mg} / \mathrm{kg} \mathrm{dw}, \sim 9.72 \%$ for K, from 2242.1 to $1600.9 \mathrm{mg}$ / $\mathrm{kg}$ dry weight (dw), $\sim 28.6 \%$ for $\mathrm{Mg}$, from 7.9 to $2.96 \mathrm{mg} / \mathrm{kg} \mathrm{dw}, \sim 62.54 \%$ for $\mathrm{Zn}$ and from 10.8 to $4.3 \mathrm{mg} / \mathrm{kg} \mathrm{dw}, \sim 60.19 \%$ for B) while a similar pattern was observed for $\mathrm{Mg}$ and $\mathrm{Mn}$ in leaves of Cukurova 1518 (from 2368.3 to $1502.7 \mathrm{mg} / \mathrm{kg} \mathrm{dw}, \sim 36.55 \%$ for $\mathrm{Mg}$ and from 0.446 to $0.057 \mathrm{mg} / \mathrm{kg}$ $\mathrm{dw}, \sim 87.22 \%$ for $\mathrm{Mn}$ ) (Table 1). Potassium, Ca, and $\mathrm{Zn}$ concentrations in leaves of Cukurova 1518 fluctuated. For example, reductions at the lowest level of $\mathrm{NaCl}$ were observed whereas increases were 


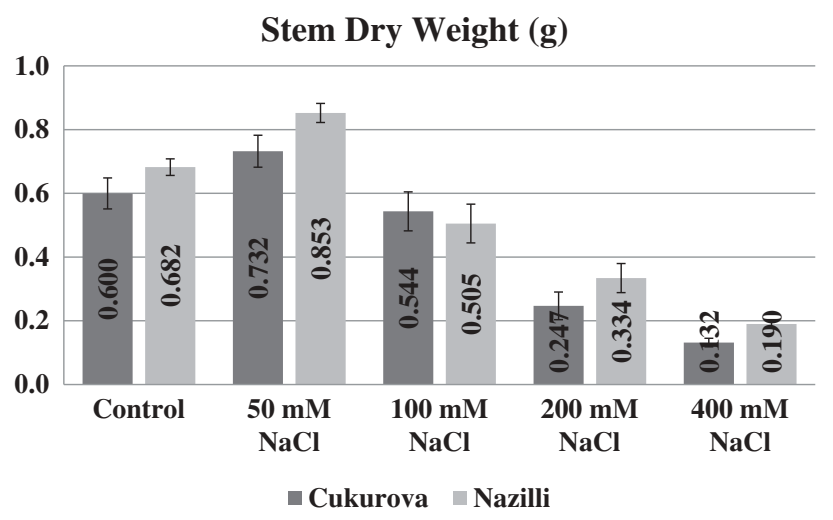

Figure 6. Stem dry weights of cotton cultivars in different $\mathrm{NaCl}$ levels $(0,50,100,200$ and $400 \mathrm{mM})$ in three months of growing period. According to the results of variance analysis and Tukey's test, the mean difference is significant at $p<0.01\left(^{*}\right)$ and $p<0.05$ $\left({ }^{* *}\right)$ levels.

observed at the highest level of $\mathrm{NaCl}$ for $\mathrm{Ca}$ (Table 1). A similar pattern was noticed for $\mathrm{Mn}$ in leaves of Nazilli $84 \mathrm{~S}$ and vice versa for $\mathrm{Ca}$ in leaves of Nazilli $84 \mathrm{~S}$. For K in leaves of Cukurova 1518, increases were seen at 50 and $200 \mathrm{mM} \mathrm{NaCl}$ levels whereas reductions were observed at 100 and $400 \mathrm{mM} \mathrm{NaCl}$ levels, comparing with the control. For B in leaves of Cukurova 1518, reductions were noticed at all levels of $\mathrm{NaCl}$ except $400 \mathrm{mM}$ level, comparing with the control. Content of $\mathrm{Fe}$ was reduced by $\mathrm{NaCl}$ treatment, with the greatest reduction observed at higher levels of $\mathrm{NaCl}$ in leaves of both cultivars. Contents of $\mathrm{Mg}, \mathrm{Fe}, \mathrm{Mn}, \mathrm{Zn}$, and $\mathrm{B}$ in stems of both cultivars decreased in the presence of $\mathrm{NaCI}$, with the greatest decrease observed at higher levels of $\mathrm{NaCI}$. Increases in stem concentrations of $\mathrm{K}$ and $\mathrm{Ca}$, were seen at all levels of $\mathrm{NaCl}$ in Nazilli 84S, relative to the control. Following the reductions at low level of $\mathrm{NaCI}$, the increments were observed but at the highest level of $\mathrm{NaCI}$, once again the reductions followed the increments in stems of Cukurova 1518.

It is thought that $\mathrm{Na}^{+}$is transported into plant cells passively via $\mathrm{K}^{+}$transport systems (Schroeder, Ward, and Gassmann 1994). There is an increase in $\mathrm{Na}^{+}$influx and a decrease in $\mathrm{K}^{+}$uptake during salt stress in plants. $\mathrm{K}^{+}$deficiency is considered to be a result of excessive uptake of $\mathrm{Na}^{+}$resulting in the inhibition of $\mathrm{K}^{+}$uptake into plant cells. Its reason could be that $\mathrm{Na}^{+}$ions are more available than $\mathrm{K}^{+}$ions in the influx transport systems. Besides, in high $\mathrm{Na}^{+}$and low $\mathrm{K}^{+}$soils, plants can accumulate $\mathrm{Na}^{+}$more than $\mathrm{K}^{+}$. Thus, herein findings are corroborated by above-earlier reports. $\mathrm{K}^{+}$accumulation increased in leaves and stems until a point but after that point $(400 \mathrm{mM} \mathrm{NaCl}$ level) reductions were seen in $\mathrm{K}$ concentration in both cultivars because of detrimental effects of $\mathrm{Na}$. This demonstrates that $\mathrm{Na}^{+}$more favorably binds to the influx $\mathrm{K}^{+}$transport systems than $\mathrm{K}^{+}$. Therefore, an increased level of $\mathrm{Na}^{+}$was observed in leaves and stems. The cells could act in preserving the $\mathrm{K}^{+} / \mathrm{Na}^{+}$ratio to keep ionic strength and osmotic pressure in balance. So, $\mathrm{K}^{+}$transportation could have been increased from roots to leaves to counteract the limited $\mathrm{K}^{+}$uptake. Perhaps this is why $\mathrm{K}^{+}$concentration level was above the baseline (control) in cells.

There was fluctuation for $\mathrm{Ca}$ in leaves of Cukurova 1518. Reductions were observed at $50 \mathrm{mM}$ (from 15.743 to $11.938 \mathrm{~g} / \mathrm{kg} \mathrm{dw}, \sim 24.17 \%$ ) and $400 \mathrm{mM}$ (from 16.787 to $12.054 \mathrm{~g} / \mathrm{kg} \mathrm{dw}, \sim 28.2 \%$ ) $\mathrm{NaCl}$ whereas increases was observed at $100 \mathrm{mM}$ (from 11.938 to $13.831 \mathrm{~g} / \mathrm{kg} \mathrm{dw}, \sim 15.86 \%$ ) and $200 \mathrm{mM}$ (from 11.938 to $16.787 \mathrm{~g} / \mathrm{kg} \mathrm{dw}, \sim 40.63 \%$ ) NaCl and a similar trend was observed for Nazilli $84 \mathrm{~S}$ (increases from 337.3 to $587.7 \mathrm{mg} / \mathrm{kg} \mathrm{dw}, \sim 74.24 \%$ at $100 \mathrm{mM} \mathrm{NaCl}$ and from 376.4 to $659.2 \mathrm{mg}$ / $\mathrm{kg} \mathrm{dw}, \sim 75.13 \%$ at $400 \mathrm{mM} \mathrm{NaCl}$ and a reduction from 587.7 to $376.4 \mathrm{mg} / \mathrm{kg} \mathrm{dw}, \sim 64.05 \%)$. There was a decrease in stems of Cukurova 1518 whereas there was an increase in stems of Nazilli 84S at all levels of $\mathrm{NaCl}$. It is widely recognized that $\mathrm{Ca}^{2+}$ plays a regulatory role involving the passive entry of $\mathrm{Na}^{+}$and in $\mathrm{K}^{+} / \mathrm{Na}^{+}$selectivity (Davies 2014; Ma et al. 2014). So, it is considered that the integrity of 


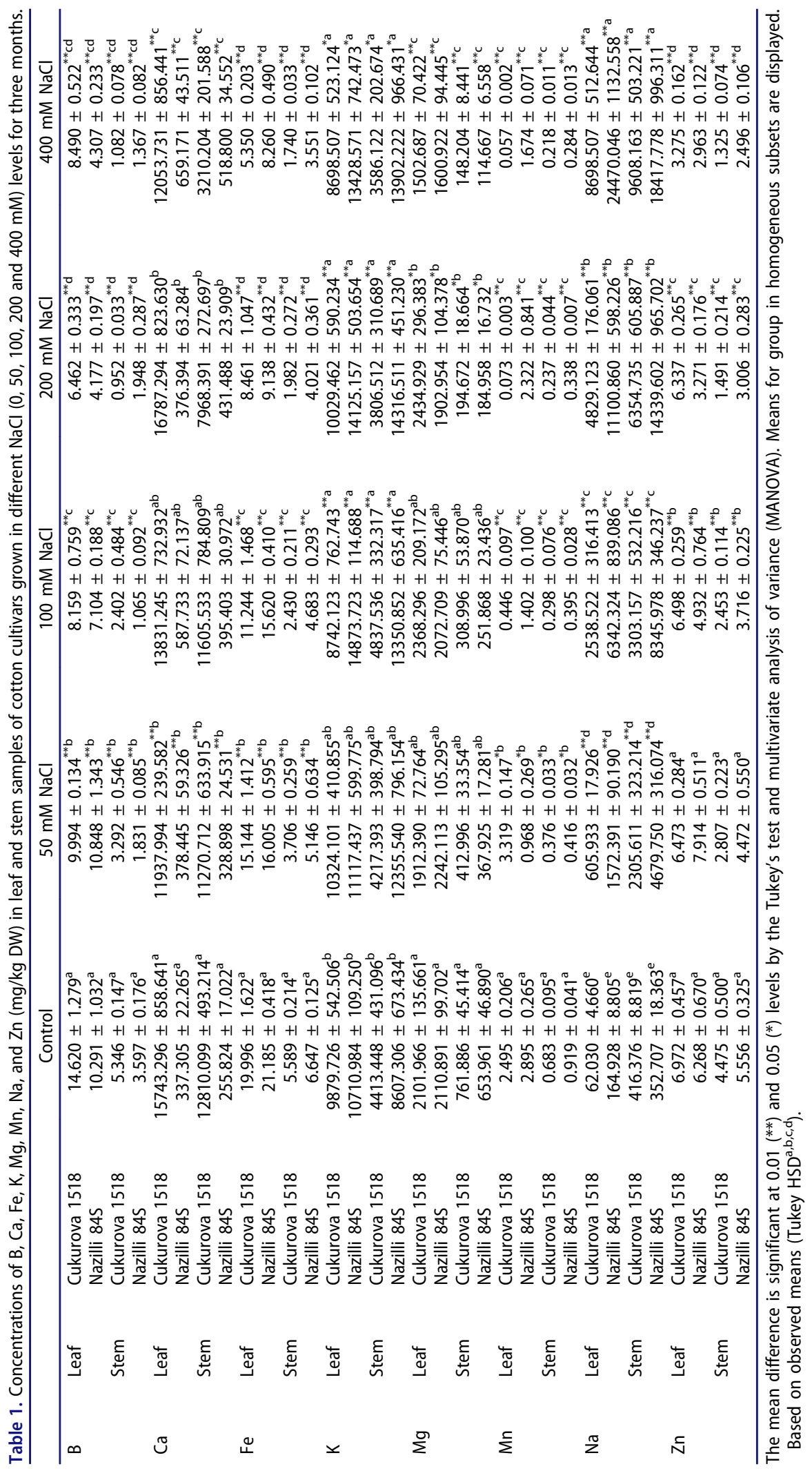


cell membranes is preserved through the maintenance of the cell levels of $\mathrm{Ca}^{2+}$, allowing the change in $\mathrm{K}^{+} / \mathrm{Na}^{+}$and the selective absorption of $\mathrm{K}^{+}$(Meloni et al. 2001). It seems that the ability of plants to retain $\mathrm{Ca}^{2+}$ is associated with their salt resistance. In our work, both of our cultivars kept the $\mathrm{Ca}^{2+}$ levels stable at all levels of $\mathrm{NaCl}$, although there were reductions and increases. But, it was obvious that the accumulation amount in leaves and stems was much higher than Nazilli $84 \mathrm{~S}$ for Cukurova 1518. For example, Ca concentration in leaves for Cukurova $1518(15.743 \mathrm{~g} / \mathrm{kg} \mathrm{dw})$ at control level was higher than Nazilli $84 \mathrm{~S}(337.3 \mathrm{mg} / \mathrm{kg} \mathrm{dw})$ and similar data were seen for all other levels.

Nonselective cation channels in the plasma membranes, which allow passive fluxes of cations into the cells (Demidchik, Davenport, and Tester 2002; Demidchik \& Maathuis, 2007; Very and Sentenac 2003) are typically permeable to a wide range of monovalent cations like $\mathrm{Na}^{+}$(Very and Sentenac 2003). These channels were also proposed by many studies as being a major pathway for $\mathrm{Na}^{+}$into the plants (Furini and Domene 2013) and many studies have confirmed the proposal (Demidchik and Tester 2002; Essah, Davenport, and Tester 2003; Maathuis and Sanders 2001). In our study, reductions were observed in concentrations of $\mathrm{Mg}, \mathrm{Fe}, \mathrm{Mn}, \mathrm{Zn}$, and $\mathrm{B}$ in leaves of both cultivars at high levels of $\mathrm{NaCl}$ but for $\mathrm{Mg}$ and $\mathrm{Mn}$, following the increments at low level of $\mathrm{NaCl}$, the reductions were seen at higher levels of $\mathrm{NaCl}$ in leaves of Cukurova 1518. A similar pattern was noticed for $\mathrm{Mg}$, Zn, and B in leaves of Nazilli 84S. There were reductions in concentrations of $\mathrm{Mg}, \mathrm{Fe}, \mathrm{Mn}, \mathrm{Zn}$, and $\mathrm{B}$ in stems of both cultivars in the presence of $\mathrm{NaCl}$. Once again, $\mathrm{Na}$ ions are considered able to bind to nonselective cation channels more favorably than other cations. Therefore, $\mathrm{Mg}, \mathrm{Fe}, \mathrm{Mn}, \mathrm{Zn}$, and B uptakes were highly disrupted in leaves and stems because of high $\mathrm{Na}^{+}$.

The data for correlation coefficients between elements' concentrations in leaves and stems of both cotton varieties were given in Table 2. Based on the obtained data from the elements' concentrations in both leaves of Nazilli and Cukurova and the elements' concentrations in both stems of Nazilli and Cukurova, relative positive correlations $(>0.52,>0.89$ ) were found between $\mathrm{B}$ and $\mathrm{Fe}$, and $\mathrm{Mg}$, $\mathrm{Mn}$ and $\mathrm{Zn}$, and $\mathrm{Fe}$ and $\mathrm{B}$, and $\mathrm{Mg}, \mathrm{Mn}$ and $\mathrm{Zn}$, and $\mathrm{Mn}$ and $\mathrm{B}$, and $\mathrm{Zn}$ and Fe. Relative negative correlations $(->0.61,->0.95)$ existed between $\mathrm{B}, \mathrm{Fe}, \mathrm{Zn}$ and $\mathrm{Na}$ were noticed. High correlations $(>0.50,>0.79)$ were detected in Cukurova groups whereas negative correlations $(->0.58,->0.86)$ were detected in Nazilli groups for $\mathrm{Fe}$ and $\mathrm{Ca}$, and $\mathrm{Zn}$ and $\mathrm{Ca}$. The data showing negative relationship existed between $\mathrm{Na}$ and other elements (in Table 3) supports the data showing negative relationship existed between $\mathrm{Na}$

Table 2. Correlation matrix of mineral nutrients in leaf and stem samples of cotton cultivars grown in different $\mathrm{NaCl}(0,50,100$, 200 and $400 \mathrm{mM}$ ) levels for three months.

\begin{tabular}{|c|c|c|c|c|c|c|c|c|}
\hline \multicolumn{9}{|l|}{ Correlation Matrix (R) } \\
\hline Pearson Correlation & B NL & Ca NL & $\mathrm{Fe} \mathrm{NL}$ & $\mathrm{K} \mathrm{NL}$ & $\mathrm{Mg} \mathrm{NL}$ & $\mathrm{Mn} \mathrm{NL}$ & $\mathrm{Na} \mathrm{NL}$ & $\mathrm{Zn} \mathrm{NL}$ \\
\hline B NS & $.461^{*}$ & $-.553^{* *}$ & $.610^{* *}$ & $-.530^{* *}$ & .180 & $.630^{* *}$ & $-.507^{* *}$ & .305 \\
\hline Ca NS & $-.710^{* *}$ & $.577^{* *}$ & $-.864^{* *}$ & $.441^{*}$ & $-.593^{* *}$ & -.294 & $.833^{* *}$ & $-.746^{* *}$ \\
\hline Fe NS & $.594^{* *}$ & $-.447^{*}$ & $.774^{* *}$ & -.311 & $.528^{* *}$ & .303 & $-.706^{* *}$ & $.664^{* *}$ \\
\hline K NS & $-.607^{* *}$ & .324 & $-.750^{* *}$ & $.559^{* *}$ & -.342 & -.396 & $.556^{* *}$ & $-.582^{* *}$ \\
\hline Mg NS & $.771^{* *}$ & $-.501^{*}$ & $.865^{* *}$ & $-.546^{* *}$ & $.461^{*}$ & .366 & $-.758^{* *}$ & $.634^{* *}$ \\
\hline Mn NS & $.549^{* *}$ & $-.456^{*}$ & $.800^{* *}$ & $-.454^{*}$ & .381 & $.450^{*}$ & $-.634^{* *}$ & $.423^{*}$ \\
\hline Na NS & $-.816^{* *}$ & $.496^{*}$ & $-.950^{* *}$ & $.513^{* *}$ & $-.707^{* *}$ & -.140 & $.930^{* *}$ & $-.760^{* *}$ \\
\hline Zn NS & $.594^{* *}$ & $-.553^{* *}$ & $.811^{* *}$ & $-.434^{*}$ & $.719^{* *}$ & .078 & $-.762^{* *}$ & $.610^{* *}$ \\
\hline Pearson Correlation & $\mathrm{BCL}$ & $\mathrm{Ca} C \mathrm{~L}$ & $\mathrm{Fe} \mathrm{CL}$ & $\mathrm{KCL}$ & $\mathrm{Mg} \mathrm{CL}$ & $\mathrm{MnCL}$ & $\mathrm{NaCL}$ & $\mathrm{ZnCL}$ \\
\hline B CS & $.716^{* *}$ & .112 & $.697^{* *}$ & .116 & -.140 & $.672^{* *}$ & $-.762^{* *}$ & $.540^{* *}$ \\
\hline $\mathrm{Ca}$ CS & $.472^{*}$ & .264 & $.772^{* *}$ & .115 & $.408^{*}$ & $.606^{* *}$ & $-.927^{* *}$ & $.791^{* *}$ \\
\hline Fe CS & $.790^{* *}$ & .120 & $.805^{* *}$ & .215 & .098 & $.748^{* *}$ & $-.748^{* *}$ & $.521^{* *}$ \\
\hline K CS & .225 & -.074 & .213 & -.122 & .201 & .208 & $-.408^{*}$ & $.504^{*}$ \\
\hline $\mathrm{Mg}$ CS & $.870^{* *}$ & .240 & $.892^{* *}$ & .213 & .199 & $.674^{* *}$ & $-.754^{* *}$ & $.495^{*}$ \\
\hline Mn CS & $.707^{* *}$ & .218 & $.644^{* *}$ & -.055 & .020 & $.542 * *$ & $-.616^{* *}$ & $.427^{*}$ \\
\hline $\mathrm{NaCS}$ & $-.617^{* *}$ & -.191 & $-.886^{* *}$ & -.385 & -.330 & $-.751^{* *}$ & $.950^{* *}$ & $-.780^{* *}$ \\
\hline $\mathrm{ZnCS}$ & $.865^{* *}$ & .218 & $.848^{* *}$ & .244 & .169 & $.662^{* *}$ & $-.760^{* *}$ & $.583^{* *}$ \\
\hline
\end{tabular}

**. Correlation is significant at the 0.01 level (2-tailed). *. Correlation is significant at the 0.05 level (2-tailed) (NL: the leaves of Nazilli 84S, NS: the stems of Nazilli 84S, CL: the leaves Cukurova 1518, and CS: the stems of Cukurova 1518). 
Table 3. Some growth parameters of cotton cultivars in different $\mathrm{NaCl}$ levels $(0,50,100,200$ and $400 \mathrm{mM})$ in three months of growing period.

\begin{tabular}{|c|c|c|c|c|c|c|}
\hline & & Control & $50 \mathrm{mM} \mathrm{NaCl}$ & $100 \mathrm{mM} \mathrm{NaCl}$ & $200 \mathrm{mM} \mathrm{NaCl}$ & $400 \mathrm{mM} \mathrm{NaCl}$ \\
\hline \multirow[t]{2}{*}{$\begin{array}{l}\text { Stem Lenght } \\
\quad(\mathrm{cm})\end{array}$} & $\begin{array}{l}\text { Cukurova } \\
1518\end{array}$ & $16.638 \pm 0.490^{\mathrm{a}}$ & $16.188 \pm 0.565^{* * a b}$ & $12.800 \pm 0.524^{* * b}$ & $8.575 \pm 0.248^{* * c}$ & $5.675 \pm 0.260^{* * d}$ \\
\hline & Nazilli 84S & $16.375 \pm 0.347^{\mathrm{a}}$ & $13.450 \pm 0.117^{* * a b}$ & $10.213 \pm 0.501^{* * \mathrm{~b}}$ & $8.175 \pm 0.433^{* *{ }^{*} c}$ & $4.260 \pm 0.535^{* * d}$ \\
\hline Leaf Fresh & Cukurova & $0.808 \pm 0.031^{\mathrm{b}}$ & $0.888 \pm 0.048^{\mathrm{a}}$ & $0.812 \pm 0.051^{b}$ & $0.600 \pm 0.075^{* * c}$ & $0.144 \pm$ \\
\hline Weight & 1518 & & & & & \\
\hline (gr) & Nazilli $84 S$ & $0.963 \pm 0.028^{b}$ & $0.985 \pm 0.031^{\mathrm{a}}$ & $0.792 \pm 0.046^{\mathrm{b}}$ & $0.617 \pm 0.085^{* * c}$ & $0.067=$ \\
\hline Leaf Dry & Cukurova & $0.174 \pm 0.007^{\mathrm{a}}$ & $0.170 \pm 0.008^{a}$ & $0.144 \pm 0.012^{* * b}$ & $0.081 \pm 0.010^{* * c}$ & $0.035 \pm$ \\
\hline Weight & 1518 & & & & & \\
\hline (gr) & Nazilli & $0.161 \pm 0.007^{\mathrm{a}}$ & $0.005^{\mathrm{a}}$ & $0.117 \pm 0.012^{* * \mathrm{~b}}$ & $0.096 \pm 0.015^{* * c}$ & $0.024 \pm 0.003^{* * d}$ \\
\hline Stem Fresh & Cukurs & 2.68 & 3.39 & $2.204 \pm 0.168^{* * \mathrm{~b}}$ & $0.917 \pm 0.114^{* * *}$ & 0.312 \\
\hline $\begin{array}{l}\text { Weight } \\
\text { (gr) }\end{array}$ & Nazilli \& & 3.064 & 2.885 & $2.140 \pm 0.164^{* * b}$ & $1.216 \pm 0.116^{* * c}$ & $0.300 \pm$ \\
\hline $\begin{array}{l}\text { Stem Dry } \\
\text { Weight }\end{array}$ & $\begin{array}{l}\text { Cukt } \\
1518\end{array}$ & $0.600 \pm 0.049^{\mathrm{ab}}$ & $0.732 \pm 0.050^{* a}$ & $0.544 \pm 0.061^{* * \mathrm{~b}}$ & $0.247 \pm 0.043^{* * *}$ & $0.132 \pm 0.011^{* * d}$ \\
\hline $\begin{array}{l}\text { Weight } \\
\text { (gr) }\end{array}$ & $\begin{array}{l}1518 \\
\text { Nazilli } 845\end{array}$ & $0.682 \pm$ & $0.853 \pm$ & 0.505 & $0.334 \pm$ & $0.190 \pm$ \\
\hline \multirow[t]{2}{*}{$\begin{array}{l}\text { Leaf Area } \\
\left(\mathrm{cm}^{2}\right)\end{array}$} & $\begin{array}{l}\text { Cukurova } \\
1518\end{array}$ & $43.966 \pm 0.801^{\mathrm{a}}$ & $36.615 \pm 1.012^{* * a b}$ & $31.927 \pm 1.006^{* * b}$ & $20.978 \pm 1.306^{*{ }^{*} c}$ & $6.801 \pm 0.112^{* * d}$ \\
\hline & Nazilli $84 S$ & $51.653 \pm 1.146^{\mathrm{a}}$ & $46.28 \pm 0.926^{* * a b}$ & $31.568 \pm 1.124^{* * b}$ & $20.764 \pm 1.197^{* * c}$ & $5.232 \pm 0.098^{* * d}$ \\
\hline
\end{tabular}

The mean difference is significant at $0.01\left(^{* *}\right)$ and $0.05\left(^{*}\right)$ levels by the Tukey's test and multivariate analysis of variance (MANOVA). Means for group in homogeneous subsets are displayed. Based on observed means (Tukey HSD ${ }^{\mathrm{a}, \mathrm{b}, \mathrm{c}, \mathrm{d}}$ ).

concentration and height, leaf-stem weights and leaf area of the cotton varieties (Note: explanation of the statistical results of Tables 1 and 2 (sentence by sentence) will be too long. Therefore, using Tukey's post-hoc tests for concentration groups will be enough for those who know the expression of Manova. The article is designed for carrying out support the relationship exists between elements).

Finally, overcoming salt stress, and achieving recovery and growth seem to necessitate more complex responses by plants. From our data, it could be said that the cotton var. Cukurova 1518 used in this work exhibited better salt tolerance. It seems that $\mathrm{Ca}$ is the most important mineral nutrient in establishing high degree salt tolerance and the amount of $\mathrm{Ca}$ in cells is critical in response to salt stress. The Ca accumulation was much higher in Cukurova 1518 than Nazilli 84S. Our data suggest that Ca may prevent excessive $\mathrm{Na}^{+}$accumulation in the cells. The accumulation rate of $\mathrm{Na}^{+}$ was significantly higher in Nazilli 84S than Cukurova 1518.

\section{Acknowledgments}

The authors wish to thank Bahcesehir University for their technical support.

\section{Funding}

This study was funded by Marmara University, Commission of Scientific Research Project under grant FEN-A030108-0016.

\section{References}

Aguilera, M., and J. M. Aguilera-Gomez. 2016. Molecular biology of viruses: Disease perspective. In Applied molecular biotechnology-The next generation of genetic engineering, eds M. S. Khan, I. A. Khan, and D. Bahr, 423-52. Boca Raton, FL: CRC Press.

Akbarimoghaddam, H., M. Galavi, A. Ghanbari, and N. Panjehkeh. 2011. Salinity effects on seed germination and seedling growth of bread wheat cultivars. Trakia Journal of Science 9 (1):43-50.

Alam, S. M. 1999. Nutrient uptake by plants under stress conditions. In Handbook of plant and crop stress, ed. M. Pessarali, 285-314. New York: Marcel Dekker.

Ali, H., T. C. Tucher, T. L. Thompson, and M. Salim. 2001. Effects of salinity and mixed ammonium and nitrate nutrition on the growth and nitrogen utilization of barley. Journal of Agronomy and Crop Science 186:223-28. 
Aragao, F. J. L., G. R. Vianna, S. B. R. C. Carvalheira, and E. L. Rech. 2005. Germ line genetic information in cotton (Gossypium hirsutum L.) by selection of transgenic meristematic cells with a herbicide molecule. Plant Science 168 (5):1227-33. doi:10.1016/j.plantsci.2004.12.024.

Ashraf, M. 2002. Salt tolerance of cotton: Some new advances. Critical Reviews in Plant Science 21:1-32. doi:10.1016/ S0735-2689(02)80036-3.

Bano, A., and M. Fatima. 2009. Salt tolerance in Zea mays (L.) following inoculation with Rhizobium and Pseudomonas. Biology and Fertility Soils 45:405-13. doi:10.1007/s00374-008-0344-9.

Berry, W. 2010. Symptoms of Deficiency in Essential Minerals. In Plant physiology, eds. L. Taiz, and E. Zeiger, 5th ed., Sunderland, MA: Sinauer Associates, Inc.

Bor, M., F. Ozdemir, and I. Turkan. 2003. The effect of salt stress on lipid peroxidation and antioxidants in leaves of sugar beet Beta vulgaris L. and wild beet Beta maritima L. Plant Science 164:77-84. doi:10.1016/S0168-9452(02) 00338-2.

Chachar, Q. I., A. G. Solangi, and A. Verhoef. 2008. Influence of sodium chloride on seed germination and seedling root growth of cotton (Gossypium hirsutum L.). Pakistan Journal of Botany 40 (1):183-97.

Davies, J. M. 2014. Annexin-mediated calcium signalling in plants. Plants 3:128-40. doi:10.3390/plants3010128.

Demidchik, V., R. J. Davenport, and M. Tester. 2002. Nonselective cation channels in plants. Annual Review of Plant Biology 53:67-107. doi:10.1146/annurev.arplant.53.091901.161540.

Demidchik, V., and M. A. Tester. 2002. Sodium fluxes through nonselective cation channels in the plant plasma membrane of protoplasts from Arabidopsis roots. Plant Physiology 128:379-87. doi:10.1104/pp.010524.

Demidhik, V., and F. J. M. Maathuis. 2007. Physiological roles of nonselective cation channels in plants: From salt stress to signaling and development. New Phytologist 175 (3):387-404. doi:10.1111/j.1469-8137.2007.02128.x.

Dong, H. 2012. Combating salinity stress effects on cotton with agronomic practices. African Journal of Agricultural Research 7 (34):4708-15. doi:10.5897/AJAR12.501.

Donohue, S. J. 2001. Conditions contributing to various plant nutritional deficiencies. Blacksburg, VA: Crop and Soil Environmental News. Virginia Cooperative Extension.

Essah, P. A., R. Davenport, and M. Tester. 2003. Sodium influx and accumulation in Arabidopsis. Plant Physiology 133:307-18. doi:10.1104/pp.103.022178.

Flowers, T. J., R. Munns, and T. D. Colmer. 2014. Sodium chloride toxicity and the cellular basis of salt tolerance in halophytes. Annals of Botany 115 (3):419-31. doi:10.1093/aob/mcu217.

Furini, S., and C. Domene. 2013. $\mathrm{K}+$ and $\mathrm{Na}+$ Conduction in selective and nonselective ion channels via molecular dynamics simulations. Biophysical Journal 105 (89):1737-45. doi:10.1016/j.bpj.2013.08.049.

Glenn, E. P., J. J. Brown, and E. Blumwald. 1999. Salt tolerance and crop potential of halophytes. Critical Reviews in Plant Science 18:227-55. doi:10.1016/S0735-2689(99)00388-3.

Hoagland, D. R., and D. I. Arnon. 1950. The water culture method for growing plants without soil. Circular 347, Agricultural Experimental Station, University of California, Berkeley, CA.

Hussain, M., M. Farooq, M. Shehzad, M. B. Khan, A. Wahid, and G. Shabir. 2012. Evaluating the performance of elite sunflower hybrids under saline conditions. International Journal of Agricultural and Biology 14:131-35.

Javid, M. G., A. Sorooshzadeh, F. Moradi, A. M. M. Sanavy Seyed, and I. Allahdadi. 2011. The role of phytohormones in alleviating salt stress in crop plants. Australian Journal of Crop Science 5 (6):726-34.

Kudoyarova, G. R., I. C. Dodd, D. S. Veselov, S. A. Rothwell, and S. Y. Veselov. 2015. Common and specific responses to availability of mineral nutrients and water. Journal of Experimental Botany 66:2133-44. doi:10.1093/jxb/erv017.

Ma, D.-M., W.-R. Xu, H.-W. Li, F.-X. Jin, L.-N. Guo, J. Wang, H.-J. Dai, and X. Xu. 2014. Co-expression of the Arabidopsis SOS genes enhances salt tolerance in transgenic tall fescue (Festuca arundinacea Schreb.). Protoplasma 251:219-31. doi:10.1007/s00709-013-0540-9.

Maathuis, F. M. J., and D. Sanders. 2001. Sodium uptake in Arabidopsis thaliana roots is regulated by cyclic nucleotides. Plant Physiology 127:1617-25. doi:10.1104/pp.010502.

Mahajan, S., and N. Tuteja. 2005. Cold, salinity and drought stresses: An overview. Archives of Biochemistry and Biophysics 444:139-58. doi:10.1016/j.abb.2005.10.018.

Meloni, D. A., M. A. Oliva, H. A. Ruiz, and C. A. Martinez. 2001. Contribution of proline and inorganic solutes to osmatic adjustment in cotton under salt stress. Journal of Plant Nutrition 24 (3):599-612. doi:10.1081/PLN100104983.

Mishra, R., H. Wang, N. R. Yadav, and T. A. Wilkins. 2003. Development of highly regenerable elite Acala cotton (Gossypium hirsutum cv. Maxxa) - a step towards genotype-independent regeneration. Plant Cell, Tissue and Organ Culture 73:21-35. doi:10.1023/A:1022666822274.

Munns, R. 1993. Physiological processes limiting plant growth in saline soils: Some dogmas and hypotheses. Plant, Cell and Environment 16:15-24. doi:10.1111/pce.1993.16.issue-1.

Munns, R. 2002. Comparative physiology of salt and water stress. Plant, Cell and Environment 25:239-50. doi:10.1046/ j.0016-8025.2001.00808.x.

Netondo, G. W., J. C. Onyango, and E. Beck. 2004. Sorghum and salinity: II. Gas exchange and chlorophyll fluorescence of sorghum under salt stress. Crop Science 44:806-11. doi:10.2135/cropsci2004.8060. 
Neumann, P. M. 1997. Salinity resistance and plant growth revisited. Plant, Cell and Environment 20:1113-19. doi:10.1046/j.1365-3040.1997.d01-139.x.

Ozyigit, I. I., and N. Gozukirmizi. 2008. High efficiency shoot and root formation from cotyledonary nodes of cotton (Gossypium hirsutum L.). Pakistan Journal of Botany 40 (4):1665-72.

Pasternak, D. 1987. Salt tolerance and crop production. Acomprehensive approach. Annual Review of Phytopathology 25:271-91. doi:10.1146/annurev.py.25.090187.001415.

Schroeder, J. I., J. M. Ward, and W. Gassmann. 1994. Perspectives on the physiology and structure of inward-rectifying K-channels in higher plants. Biophysical implications for K-uptake. Annual Review Biophysics and Biomolecular Structure 23:4441-71. doi:10.1146/annurev.bb.23.060194.002301.

Seckin, B., A. H. Sekmen, and I. Turkan. 2009. An enhancing effect of exogenous mannitol on the antioxidant enzyme activities in roots of wheat under salt stress. Journal of Plant Growth Regulation 28:12-20. doi:10.1007/s00344-0089068-1.

Shrivastava, P., and R. Kumar. 2015. Soil salinity: A serious environmental issue and plant growth promoting bacteria as one of the tools for its alleviation. Saudi Journal of Biological Sciences 22 (2):123-31. doi:10.1016/j. sjbs.2014.12.001.

Staple, R. C., and G. H. Toenniessen. 1984. Salinity Tolerance in Plant Strategies for Crop Improvement. New York: Wiley.

Tabur, S., and K. Demir. 2010. Role of some growth regulators on cytogenetic activity of barley under salt stress. Plant Growth Regulation 60:99-104. doi:10.1007/s10725-009-9424-6.

Tester, M., and R. Davenport. 2003. $\mathrm{Na}^{+}$tolerance and $\mathrm{Na}^{+}$transport in higher plants. Annals of Botany 91:503-27. doi:10.1093/aob/mcg058.

Tiwari, J. K., A. D. Munshi, R. Kumar, R. N. Pandey, A. Arora, J. S. Bhat, and A. K. Sureja. 2010. Effect of salt stress on cucumber: $\mathrm{Na}^{+} / \mathrm{K}^{+}$ratio, osmolyte concentration, phenols and chlorophyll content. Acta Physiologiae Plantarum 32:103-14. doi:10.1007/s11738-009-0385-1.

Very, A.-A., and H. Sentenac. 2003. Molecular mechanisms and regulation of $\mathrm{K}^{+}$transport in higher plants. Annual Review of Plant Physiology 54:575-603.

Zhu, J.-K. 2001. Plant salt tolerance. Trends in Plant Science 6:66-71. doi:10.1016/S1360-1385(00)01838-0. 